\title{
PENTINGNYA PENGELOLAAN PERPUSTAKAAN SEKOLAH TERHADAP MINAT BACA SISWA
}

\author{
Yessy Fusvita Dewi \\ yessyfusvita@gmail.com \\ Universitas Negeri Padang
}

\begin{abstract}
ABSTRAK
Perpustakaan merupakan salah satu layanan khusus atau prasarana yang secara tidak langsung menunjang proses belajar dan mengajar disekolah namun berperan penting dalam meningkatkan minat baca siswa siswa disekolah. Minat membaca siswa akan dipengaruhi oleh hambatan dalam pengelolaan perpustakaan disekolah, layanan dalam tata ruang di perpustakaan, Layanan dalam referensi di perpustakaan, Layanan dalam sirkulasi di perpustakaan, Strategi yang dilakukan dalam meningkatkan minat membaca pada siswa adalah dengan melakukan strategi khusus lebih menerapkan peran guru dan pustakawan.
\end{abstract}

Kata kunci : Perpustakaan, minat baca siswa 


\section{LATAR BELAKANG MASALAH}

Perpustakaan merupakan salah satu layanan khusus atau prasarana yang secara tidak langsung menunjang proses belajar dan mengajar disekolah namun berperan penting dalam kelancaran proses belajar dan mengajar. Selain sebagai tempat informasi perpustakaan juga merupakan pembentukan budaya membaca seja dini.

Dalam jurnal (Pri, 2012) Pengelolaan layanan perpustakaan sangat penting dalam meningkatkan minat baca terhadap siswadisekolah, baik dari sisi tata ruangan yang rapi dan nyaman, sumber-sumber yang dicari pun lengkap, dan layanan lainnya.

Minat baca siswa akan dipengaruhi oleh sarana dan prasarana yang ada diperpustakaan sekolah. Seiring perkembangan zaman yang modern ini sehingga untuk mencari informasi dan tugas-tugaspun melalui internet lebih mudah namun tidak semua referensi yang relevan dan banyak pengaruh yang lain menggunakan internet. Sehingga minat baca menjadi berkurang dan pengaruh lain yang menyebabkan minat baca kurang relative adalah kurangnya jam yang diberikan sekolah untuk membaca diperpustakaan dan pemberian tugas oleh gurupun kurang maksimal.

\section{METODE PENELITIAN}

Jenis penelitian yang dilakukan adalah pendekatan kualitatif, mengkaji penelitian secara mendalam dan penelitian deskriptif, untuk menggambarkan kondisi dari sesuatu.

Pengumpulan data dilakukan pengamatan langsung dengan pencacatan sistematis terhadap fenomena yang terjadi, wawancara dalam pengumpulan data. Bagaimana minat baca siswa- siswa terhadap referensi yang telah disediakan perpustakaan serta berapa banyak dan sering para siswa mengunjungi perpustakaan.

\section{KAJIAN TEORI / PEMBAHASAN}

Perpustakaan merupakan salah satu layanan khusus atau prasarana yang secara tidak langsung menunjang proses belajar dan mengajar disekolah namun berperan penting dalam meningkatkan minat baca siswa - siswa disekolah.

Minat membaca siswa akan dipengaruhi oleh hambatan dalam pengelolaan perpustakaan disekolah, diantaranya hambatan yang terjadi diantaranya: dengan keterbatasan koleksi buku atau referensi,tenaga pustakawan kurang professional.

Dalam jurnal (Basri, 2012) layanan dalam tata ruang di perpustakaan untuk meningkatkan siswa dalam membaca, bagaimana penataan perpustakaan dan letaknya apakah strategis dan baiknya jauh dari kebisingan. Kemudahan bagi siswa jika penataan ruangan nya rapi seperti rungan lobi ruangan tempat barang. Ruang koleksi buku dan ruangan baca dipisahkan. Dalam kenyamanan diperlukan juga pencahayaan yang terang serta sirkulasi udara yang baik.

Layanan dalam referensi di perpustakaan dengan adanya ruangan yang sangat nyaman dalam membaca. Layanan yang digunakan adalah kalatog yang masih manual namun setiap tahun diadakan penambahan referensi yang baru.

Layanan dalam sirkulasi di perpustakaan dengan adanya pelayanan peminjaman maupun pengembalian buku yang dipinjam oleh siswa. Adanya kartu peminjaman buku serta tata tertib dalam perpustakaan.

Strategi yang dilakukan dalam meningkatkan minat membaca pada siswa adalah dengan melakukan strategi khusus lebih menerpkan peran guru dan pustakawan untuk membuat program agar menggerakkan 
siswa untuk membaca buku serta meningkatkan layanan perpustakaan. Peran kepala sekolah mengkoordinir bersama dengan tenaga pustaka.

Strategi lain yang adakan adalah adanya kerja sama antar pustaka keliling yang juga menyediakan referensi. Mengadakan lomba karya puisi pada acara kegiatan HUT RI dengan sendirinya akan memotivasi siswa untuk membaca dan berkarya.

\section{KESIMPULAN DAN SARAN}

Berdasarkan pembahasan diatas dapat disimpulkan bahwa pengelolaan layanan pada perpustakaan dapat meningkatkan minat membaca siswa, dengan meletakkan perpustakaan pada letak yang mudah dijangkau dan jauh dari kebisingan, ruang-ruang yang disediakan perpustakaan sesuai dengan masingmasing fungsinya,factor cahaya dan udara yang memadai.

Upaya yang dilakukan sekolah dalam menunjang minat membaca siswa adalah dengan adanya peran penting guru aktif dan tenaga perpustakaan. Guru memberikan pembelajaran dan tugas agar siswa memnafaatkan adanya perpustakaan dan layanan yang sangat berkualitas.

Saran yang diberikan buat kepala sekolah agar kepala sekolah sangat berperan penting dan aktif untuk menyediakan dana tambahan terhadap pengadaan sarana perpustakaan, alat tekhnologi dan guru agar selalu aktif memberkan pembelajaran yang memnafaatkan perpustakaan dengan begitu siswa akan termotivasi dan meningkatkan minat membaca diperpustakaan. 


\section{DAFTAR PUSTAKA}

Basri. (2012). Pengelolaan Layanan Perpustakaan Dalam Peningkatan Minat Baca Siswa. 1-19.

Pri, U. (2012). Peranan Perpustakaan Sekolah Dalam Meningkatkan Minat Baca Siswa. Jurnal Ilmu Informasi Perpustakaan Dan Kearsipan, 1(1), 270-273. 